\section{Douching Practices among Hausa-Fulani Pregnant Women With and Without Bacterial Vaginosis in Zaria, Northwest Nigeria}

\section{Abstract}

Objective: The objective of this study was to examine patterns of douching practices and their association to vaginal infection among Hausa-Fulani pregnant women in Zaria, Northwest Nigeria.

Study design: This health facility-based study was a descriptive cross-sectional investigation, with laboratory analysis for bacterial vaginosis and other vaginal flora.

Results: Of 220 participants, $85.5 \%$ consented to regular douching practices. Commonly identified methods of douching were using hand to insert plain water (80.0\%), insertion of toilet soap (55.0\%), using warm water plus disinfectant/salt/ black soap (18.6\%) and using a jet or stream of water (8.6\%). Frequent douching was associated with douching during bathing (69.5\%), after passing urine (34.1\%), after sexual intercourse (16.4\%), before sexual intercourse $(5.9 \%)$ and at any other times (6.8\%). Pregnant women who douche using fingers to insert plain water were over $1 \frac{1}{2}$ times more likely to have bacterial vaginosis $\left(\chi^{2}=1.30, P\right.$-value $=0.25$, $\mathrm{OR}=1.67,95 \% \mathrm{Cl}: 0.69,4.09)$ and those who douche after sexual intercourse were about $3 \frac{1}{2}$ times more likely to develop Bacterial vaginosis $\left(\chi^{2}=8.88, P\right.$-value $=0.003$, $\mathrm{OR}=3.42,95 \% \mathrm{Cl}: 1.47,7.93)$. Douching during bathing and after sexual intercourse were more prevalent among subjects aged Bacterial vaginosis positive women aged $30-34$ years (100.0\%) and those aged $35-39$ years $(75.0 \%)$ respectively.

Conclusions: The practice of douching was common among the Hausa-Fulani ethnic group in Nigeria. Further studies are desirable to confirm douching practices and various vaginal pathology for effective control, education, and management of female genital tract.

Keywords: Douching; Hausa-Fulani; Vaginal

\section{Victor Ajayi ${ }^{1}$ and Bamgboye M Afolabi²

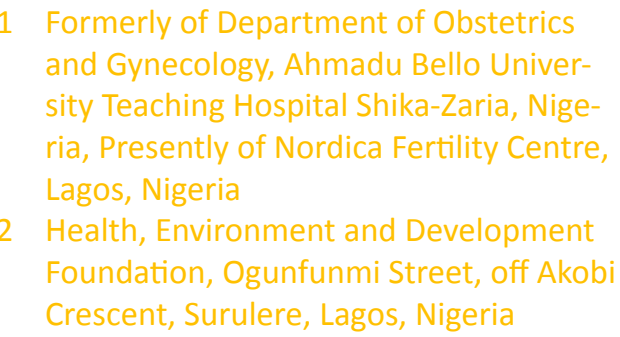

Corresponding author:

Bamgboye M Afolabi

\section{bmafolabi@gmail.com}

Health, Environment and Development Foundation, 18, Ogunfunmi Street, Off Akobi Crescent, Surulere, Lagos, Nigeria.

Tel: $+234(0) 8058658029$

Citation: Ajayi V, Afolabi BM. Douching Practices among Hausa-Fulani Pregnant Women With and Without Bacterial Vaginosis in Zaria, Northwest Nigeria. Transl Biomed. 2016, 7:4.

Received: November 07, 2016; Accepted: November 24, 2016; Published: December 05, 2016

\section{Introduction}

Douching, or the process of applying liquid or semi-liquid, powdery or herbal substances into the vagina for various reasons may have been an age-old practice in many cultures [1]. Douching probably originated from the time when the vagina was regarded as unclean and women menstrual period was erroneously viewed as a filthy process. Like any other orifice of the body such as the eyes, ears, mouth, nose or rectum, the vagina also possesses natural systems to keep itself healthy. Just like the eyes secrete tears from lacrimal glands, the ears produce wax, the nostrils produce mucous and the mouth produces saliva, the vaginal produces its own organic secretions that are expected to kept it clean. It also has its own acid pH of 3 produced by glycogen degradation to lactic acid in vaginal epithelial cells functioning as a defense mechanism against invading pathogens. The surfaces of vaginal walls, which are usually moist, are easily separable due to lubrication by about $1 \mathrm{ml}$ of basal vaginal fluid (BVF). Sources of BVF which collect in the vagina are from the peritoneal fluid, fluid from the entire uterine system which includes the follicles, the fallopian tubes, the uterus itself, the cervix and the vaginal 
secretion. Other sources of vaginal BVF are the Bartholin's and Skene's gland.

The epidemiology of douching, women's behavioral pattern to it, substances used and reasons behind douching as well as its health implication have been studied extensively, mostly outside of Africa [2,3]. Surveys have shown that douching practice was common in the United States [4,5] Martino, et al. stated that [6] douching prevalence varies according to race, and age cohort and Diclemente argued that increased age [7], lower socioeconomic status, and older partners are probable relevant risk factors for douching among African American adolescents.

One study in Turkey found that many women who practiced vaginal douching believed in its health benefits [8]. Another study reported age, religion, place of residence, and poverty influence behavioral attitudes towards douching and that most women who practiced douching alleged it to be a routine conduct [9]. The belief of some adult women in the southeastern United States is that douching is necessary for good hygiene [5]. Numerous research studies confirm that women of AfricanAmerican ancestry douche more than others [10-12].

Bacterial vaginosis and vaginal douching are both reported to be more common in African-American and Caribbean than white women [13]. Surveys of adolescents and adults who douche reveal that women are more likely to douche if they have a history of one or more sexually transmitted diseases (STDs), including HIV and herpes simplex type 2 infection [14-17]. While various studies associate douching with various sexually and non-sexually transmitted infections of the genital tract such as Bacterial vaginosis [18], Chlamydia trachomatis [19], pelvic inflammatory disease [20] and to gynecological pathologies such as endometriosis and upper genital tract infection [21], a study actually documented a beneficial effect of douching in prevention against cervical cancer [22] and another contested any association between douching and pelvic inflammatory disease [23].

Apart from infertility and fibroid, vaginal indications such as abnormal odor, either accompanied by discharge or not, seem to be cause of gynaecological visits or referral [24]. Earlier publications declared that the occasionally unpleasant odor from normal vaginal fluid [25] probably emanates from presence of infection with Bacterial vaginosis [13], though in some cases neither bacterial vaginosis nor any other invading pathogens are confirmed in symptomatic women $[26,27]$. Invariably, the practice of douching has been associated with vaginal odor [28].

Although one study opined that vaginal douching and vaginal substance use is a common practice in sub-Saharan Africa [29], douching practices among various ethnic groups in West Africa have not been widely studied hence scanty data on douching is available in this geographical location. Therefore, the main objective of this study was to explore vaginal douching practices among a cohort of pregnant women in Nigeria. Information gather can help as in planning a more robust study on douching and its perceived association with personal hygiene, genital infection and other gynecological and obstetric pathologies not only in pregnancy but prior to or after a woman has delivered.

\section{Methods}

Regular Antenatal Clinic (ANC) holds once weekly at Ahmadu Bello University Teaching Hospital, Shika area of Zaria City, Kaduna State of Nigeria. Between 40 and 60 women were usually seen at ANC where pregnancies were not only monitored for any present or impending anomaly but the pregnant women were also screened for high blood pressure, proteinuria and infections such as HIV. In the 3-month period of April and June of 2008, a total of 244 pregnant women consulting for the first time were seen at this ANC and, in addition to the regular clinical examinations, were also screened for bacterial vaginosis. In addition, questionnaires were served to these pregnant women to assess douching practices among this specific ethnic group.

The study was cross-sectional and descriptive. Pregnant woman who presented at the ANC for the first time, were admitted into the study. The tripartite study included (i) clinical examination (ii) laboratory investigation for Bacterial vaginosis and (iii) questionnaire administration to all eligible patients.

The study population was pregnant women who agreed to participate in the study and who were residing in Zaria City in Kaduna State, one of the five divisions of the Northwest geo-political zone in Nigeria. The Hausa-Fulani ethnic group, who dominate most parts of these states, are mostly traders, herdsmen and farmers, though some work in government offices as administrators.

Each consecutive pregnant woman who were attending their first ANC into the study was recruited into the study. Inclusion criteria were then (i) attending ANC for the first time (ii) resides in Zaria and not just visiting (iii) black indigenous Nigerian (iv) willing to participate in the study. The exclusion criteria were (i) those with severe systemic diseases such as diabetes mellitus, high blood pressure demonstrated kidney diseases (ii) presence of uterine anomaly and placenta abruption and cervical incompetence (iii) multiple pregnancy (iv) antibiotic consumption two weeks prior to study.

Baseline demographic information and outline of reproductive, gynaecological and medical history of each patient was recorded. The questionnaire focused on douching practices and any adverse event in current pregnancy.

At first point of contact at the ANC, the study subjects were briefed about the study, instructed on the importance of coming early to ANC, briefed about the study and encouraged to participate. It was clearly explained to them that they would still enjoy full benefit of ANC should they decide not to participate in the study. The advantages of participating in the study was also clearly explained to them. Only 4 (1.8\%) women of the 224 women who were initially recruited decided not to participate the main reason being that their husband was away and had had not been informed.

\section{Privacy and Confidentiality}

Confidentiality was maintained by interviewing, performing clinical examination and collecting specimen for laboratory analysis from each pregnant woman in a private, well-lit and cool consulting room. 


\section{Questionnaire Study on Douching}

The structured questionnaire was initially pre-tested and adjusted to fit the respondents. The questionnaire was at first constructed in English language and later translated into Hausa language and back into English language. Mostly female health workers, especially trained for the purpose, explained the study to the pregnant women, screened each one of them for eligibility, obtained informed consent and recorded responses of the pregnant women on the questionnaire served. Douching practices, especially method and time of douching were extracted from the pregnant women.

\section{Collection of Specimen}

To collect vaginal swabs, a sterile, un-greased speculum was inserted into the vaginal orifice and opened to expose the vaginal canal and the cervix. The $\mathrm{pH}$ of vaginal secretion was measured using a pH strip. Thereafter, a dry, sterile cotton on stick was used to collect secretion or substances from the posterior fornix of the vagina. This wet smear of vaginal secretion from the posterior fornix was then mixed with normal saline and examined under an electric microscope with magnification power of $x 400$. This was to identify (i) clue cells and (ii) bacteria morphocytes. Each sample was then processed per Amsel and Nugent criteria and cultured for the offending organisms. Ancillary investigations included screening for anemia and for Human Immuno-Deficient Virus (HIV).

\section{Diagnosis}

Classical Amsel's criteria and Nugent score were used to ascertain diagnostic confirmation of Bacterial vaginosis. Using Amsel's criteria, a minimum of three out of four criteria should be present for diagnosis of to be confirmed. These 4 criteria are (i) thin, white homogenous discharge, (ii) clue cells on microscopy, (iii) $\mathrm{pH}$ of vaginal fluid greater than 4.5 , and (iv) release of fishy odor on adding alkali ( $10 \%$ potassium hydroxide) or positive whiff test.

Nugent score, the main diagnostic test, approximates comparative quantity of bacteria morphotypes, apportioning scores of between 0 and 10 . While a score $>6$ is confirmatory of Bacterial vaginosis, score $<4$ indicates normal vaginal flora and score of 4-6 is intermediate.

\section{Data Management}

Data collected was entered into a laptop computer and coded accordingly. Data analysis was conducted using SPSS computer software version 15.0. Frequency tables were constructed for variables that were categorical. Cross-tabulations, Student's t-test and $\chi^{2}$ (Chi-square) analysis were employed where appropriate. Significance was considered at a $p$-value of $<0.05$. The resulting data were illustrated as Tables and figure.

\section{Ethical Considerations}

Ethical considerations involved taking verbal informed consents from the pregnant women enlisted in the study. Data confidentiality and patient anonymity and privacy were ensured by coding and by not using the name of any participant in the study. The Ethical Committee of ABUTH Zaria approved the study protocol.

\section{Results}

Approximately $34 \%$ of the 220 pregnant women who were seen at the Antenatal Clinic of the tertiary health facility where this study was carried out were aged 25-29 years. Surprisingly, the proportion of those aged $\geq 40$ years was higher $(14.6 \%)$ than those aged $35-39$ years (12.3\%) (Table 1). Most of the subjects (32.7\%) had secondary education, however, about $32 \%$ did not have any formal education while only $13.6 \%$ attained postsecondary education. Almost $40 \%$ of them were housewives with no other occupation and $35.9 \%$ were engaged in a polygamous matrimony. Only $3.1 \%$ of the pregnant women reported for ANC in the first trimester of pregnancy, indicating that early medical check-up is rare until the second trimester (81.3\%) among the ethnic group of study.

Laboratory analysis of vaginal smear indicated that 32 (14.5\%) of the pregnant women were positive for Bacterial vaginosis and HIV screening showed only $4.5 \%$ were positive. The highest proportion of pregnant women with $\mathrm{pH}$ of $\leq 4.5$ was among those aged 25-29 years. This age group also had the highest proportion of women with Clue cells present $(40.6 \%)$, positive Whiff test $(45.1 \%)$, vaginal discharge $(30.2 \%)$ and positive Bacterial vaginosis (50.0\%). The highest proportions of pregnant women with Clue cells present (46.9\%), positive Whiff test (34.5\%), vaginal discharge (42.9\%), Bacterial vaginosis (34.4\%) and HIV positivity $(60.0 \%)$ were found among those with no formal education (Table 2). The Table also illustrates morbidity patterns of study subjects by various educational levels, indicating that the highest proportions of pregnant women with Bacterial vaginosis (34.4\%), HIV positivity $(60.0 \%)$ vaginal discharge $(42.9 \%)$ and positive Clue cells (46.9\%) were among the group with no formal education.

Table 1 Socio-demographic characteristics of respondents.

\begin{tabular}{|c|c|c|c|}
\hline Variable & Item & Frequency & $\%$ \\
\hline \multirow{5}{*}{ Age group } & $20-24$ & 57 & 25.9 \\
\hline & $25-29$ & 74 & 33.6 \\
\hline & $30-34$ & 30 & 13.6 \\
\hline & $35-39$ & 27 & 12.3 \\
\hline & $\geq 40$ & 32 & 14.6 \\
\hline \multirow{4}{*}{ Formal Education } & Non & 70 & 31.8 \\
\hline & Elementary & 48 & 21.8 \\
\hline & Secondary & 72 & 32.7 \\
\hline & Post-secondary & 30 & 13.6 \\
\hline \multirow{5}{*}{ Occupation } & Trader & 41 & 18.6 \\
\hline & Government worker & 17 & 7.7 \\
\hline & Artisan & 59 & 26.8 \\
\hline & Student & 16 & 7.3 \\
\hline & Housewife & 87 & 39.6 \\
\hline \multirow{2}{*}{ Matrimony } & Monogamous & 141 & 64.1 \\
\hline & Polygamous & 79 & 35.9 \\
\hline \multirow{4}{*}{ Number of children } & 0 & 42 & 19.1 \\
\hline & 1 & 36 & 16.4 \\
\hline & 02-Apr & 84 & 38.2 \\
\hline & $\geq 5$ & 58 & 26.4 \\
\hline \multirow{3}{*}{ Trimester } & First & 11 & 3.1 \\
\hline & Second & 172 & 81.3 \\
\hline & Third & 37 & 15.6 \\
\hline
\end{tabular}


Using fingers of the hand to insert plain water was the most common method of douching $(153,80.0 \%)$ followed by insertion of toilet soap $(121,55.0 \%)$. Using a jet or stream of water was the least prominent method $(19,8.6 \%)$ of douching (Table 3). Pregnant women who used fingers to insert plain water for douching (25, 78.1\%) were 1.67 times more likely to be positive for bacterial vaginosis than those who use other methods of douching. The most prevalent time of douching was during bathing $(153,69.5 \%)$ followed by after urinating $(75,34.1 \%)$. Those who douched after sexual intercourse were about $3 \frac{1}{2}$ times more likely to have bacterial vaginosis than those douched at other times $\left(\chi^{2}=3.42\right.$, $P$-value $=0.25, O R=1.67,95 \% \mathrm{Cl}: 0.69,4.09)$. Incidentally, those who douched before sex were only 1.8 times more likely to have bacterial vaginosis when compared to those who douched during bathing, after urinating or at other times.

Douching practices in terms of method (Figure 1) and timeperiod (Figure 2) and in terms of presence or absence of Bacterial vaginosis were assessed per age group and educational status, as shown in Table 4. Overall, using fingers to insert plain water was more common in age $25-29(90.5 \%)$ and in those with no formal education. However, insertion of toilet soap was practiced more in younger age group of $20-24(71.9 \%)$ and among those with elementary educational status (60.4\%). Douching before or after sexual intercourse was observed more in age group 35-39 years (14.8\% and $29.6 \%$ respectively) and in those with secondary (6.9\%) and elementary (22.9\%) educational levels respectively. Among those with bacterial vaginosis, using finger to insert plain water was most prevalent in age group 25-29 (93.8\%) and among those with no formal education (100.0\%) while insertion of toilet soap was found more in age group $30-34$ years $(75.0 \%)$ and among those with post-secondary education (66.7\%). All women aged $30-34$ years $(100.0 \%)$ and $9(81.8 \%)$ of those with formal education reported douching during bathing. Douching after sexual intercourse was noted more in pregnant women aged 35$39(75.0 \%)$ and among those with primary $(44.4 \%)$ and secondary (44.4\%) education respectively.

Table 2 Clinical findings by age group (years) and by educational status.

\begin{tabular}{|c|c|c|c|c|c|c|c|c|c|c|c|c|c|}
\hline \multirow{3}{*}{ 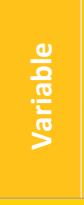 } & \multirow{3}{*}{ Item } & \multicolumn{2}{|c|}{$\begin{array}{l}\text { Characteristics of } \\
\text { vaginal fluid ( } \mathrm{pH} \text { of } \\
\text { vaginal fluid) }\end{array}$} & \multicolumn{2}{|c|}{ Clue cell } & \multicolumn{2}{|c|}{ Whiff test } & \multicolumn{2}{|c|}{$\begin{array}{c}\text { Vaginal discharge } \\
\text { on examination }\end{array}$} & \multicolumn{2}{|c|}{ Bacterial Vaginosis } & \multicolumn{2}{|c|}{ HIV status } \\
\hline & & $\leq 4.5$ & $>4.5$ & Present & Absent & Positive & Negative & Yes & No & Positive & Negative & Positive & Negative \\
\hline & & Freq. (\%) & Freq. (\%) & Freq. (\%) & Freq. (\%) & Freq. (\%) & Freq. (\%) & Freq. (\%) & Freq. (\%) & Freq. (\%) & Freq. (\%) & Freq. (\%) & Freq. (\%) \\
\hline \multicolumn{2}{|c|}{$\begin{array}{l}\text { All pregnant } \\
\text { women }\end{array}$} & $15(6.8)$ & $205(93.2)$ & 64 (29.1) & 156 (70.9) & $113(51.4)$ & $107(48.6)$ & $63(28.6)$ & $157(71.4)$ & $32(14.5)$ & $188(85.5)$ & $10(4.5)$ & $210(95.5)$ \\
\hline \multirow{5}{*}{ 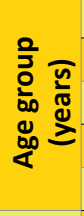 } & 20-24 & $3(20.0)$ & 54 26.3) & $12(18.8)$ & $45(28.8)$ & $29(25.7)$ & $28(26.2)$ & $17(30.2)$ & $40(25.5)$ & $8(25.0)$ & 49 (26.1) & $3(30.0)$ & $54(25.7)$ \\
\hline & $25-29$ & $5(33.3)$ & 69 (33.7) & $26(40.6)$ & $48(30.8)$ & $51(45.1)$ & $23(21.5)$ & $17(30.2)$ & $57(36.3)$ & $16(50.0)$ & $58(30.9)$ & $2(20.0)$ & 72 (34.3) \\
\hline & $30-34$ & $3(20.0)$ & $27(13.2)$ & $9(14.1)$ & $21(13.5)$ & $9(8.0)$ & $21(19.6$ & 10 (15.9) & $20(12.7)$ & $4(12.5)$ & $26(13.8)$ & $3(30.0)$ & 27 (12.9) \\
\hline & $35-39$ & $1(6.7)$ & $26(12.7)$ & $10(15.6)$ & $17(10.9)$ & $14(12.4)$ & $13(12.1)$ & $15(23.8)$ & $12(7.6)$ & $4(12.5)$ & $23(12.8)$ & $2(20.0)$ & 25 (11.9) \\
\hline & $\geq 40$ & $3(20.0)$ & $29(14.1)$ & 7 (10.9) & $25(16.0)$ & $10(8.8)$ & $22(20.6)$ & $4(6.3)$ & $28(17.8)$ & $0(0.0)$ & $32(17.0)$ & $0(0.0)$ & $32(15.2)$ \\
\hline \multirow{4}{*}{ 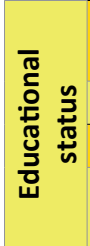 } & $\begin{array}{l}\text { No formal } \\
\text { education }\end{array}$ & $3(20.0)$ & 67 (32.7) & 30 (46.9) & $40(25.6)$ & $39(34.5)$ & 31 (29.0) & 27 (42.9) & $43(27.4)$ & $11(34.4)$ & 59 (31.4) & $6(60.0)$ & $64(30.5)$ \\
\hline & Elementary & 5 (33.3) & $43(21.0)$ & $22(34.4)$ & $26(16.7)$ & $29(25.7)$ & $19(17.8)$ & $20(31.7)$ & $28(17.8)$ & $9(28.1)$ & $39(20.7)$ & $2(20.0)$ & 46 (21.9) \\
\hline & Secondary & $3(20.0)$ & 69 (33.7) & $9(14.1)$ & $63(40.4)$ & $34(30.0)$ & $38(35.5)$ & $11(17.5)$ & $61(38.9)$ & $9(28.1)$ & $63(33.5)$ & $1(10.0)$ & $71(33.8)$ \\
\hline & $\begin{array}{c}\text { Post- } \\
\text { secondary }\end{array}$ & $4(26.7)$ & $26(12.7)$ & $3(4.7)$ & 27 (17.3) & $11(9.7)$ & 19 (17.8) & $5(7.9)$ & 25 (15.9) & $3(9.4)$ & $27(14.4)$ & $1(10.0)$ & $29(13.8)$ \\
\hline
\end{tabular}

Table 3 Prevalence, method, and time of douching by presence or absence of bacterial vaginosis.

\begin{tabular}{|c|c|c|c|c|c|c|c|c|}
\hline \multirow[t]{2}{*}{ Variable } & \multirow[t]{2}{*}{ Item } & \multirow[t]{2}{*}{ Total (\%)! } & \multicolumn{2}{|c|}{$\begin{array}{c}\text { Bacterial vaginosis positive } \\
\qquad(\mathrm{n}=32,14.5 \%)\end{array}$} & \multicolumn{2}{|c|}{$\begin{array}{c}\text { Bacterial vaginosis negative } \\
\qquad(\mathrm{n}=188,85.5 \%)\end{array}$} & \multirow[t]{2}{*}{$\chi^{2}$ (P-value) } & \multirow[t]{2}{*}{ OR $(95 \% \mathrm{Cl})$} \\
\hline & & & Freq. & $\%$ & Freq. & $\%$ & & \\
\hline \multirow{2}{*}{$\begin{array}{l}\text { Douching } \\
\text { practices }\end{array}$} & Yes & $188(85.5)$ & 26 & 81.3 & 162 & 86.2 & \multirow{2}{*}{$0.53(0.47)$} & \multirow{2}{*}{$0.70(0.26,1.85)$} \\
\hline & No & $32(14.5)$ & 6 & 18.7 & 26 & 13.8 & & \\
\hline \multirow{4}{*}{$\begin{array}{l}\text { Method of } \\
\text { douching }\end{array}$} & $\begin{array}{c}\text { Using fingers to insert plain } \\
\text { water }\end{array}$ & $153(80.0)$ & 25 & 78.1 & 128 & 68.1 & $1.30(0.25)$ & $1.67(0.69,4.09)$ \\
\hline & Insertion of toilet soap & $121(55.0)$ & 13 & 40.6 & 108 & 57.4 & $3.13(0.08)$ & $0.51(0.23,1.09)$ \\
\hline & $\begin{array}{c}\text { Using warm water and } \\
\text { disinfectant/salt/black soap }\end{array}$ & $41(18.6)$ & 5 & 15.6 & 36 & 19.1 & $0.22(0.64)$ & $0.78(0.28,2.17)$ \\
\hline & Using a jet or stream of water & $19(8.6)$ & 2 & 6.3 & 17 & 9 & $0.03(0.86)$ & $0.67(0.15,3.05)$ \\
\hline \multirow{5}{*}{$\begin{array}{l}\text { Time of } \\
\text { douching }\end{array}$} & During bathing & $153(69.5)$ & 21 & 65.6 & 132 & 70.2 & $0.27(6.0)$ & $0.81(0.37,1.79)$ \\
\hline & After urinating & $75(34.1)$ & 7 & 21.9 & 68 & 36.2 & $2.49(0.11)$ & $0.49(0.20,1.20)$ \\
\hline & After sexual intercourse & $36(16.4)$ & 11 & 34.4 & 25 & 13.3 & $8.88(0.003)$ & $3.42(1.47,7.93)$ \\
\hline & Before sexual intercourse & $13(5.9)$ & 3 & 9.4 & 10 & 5.3 & $0.24(0.62)^{*}$ & $1.84(0.48,7.09)$ \\
\hline & At other times & $15(6.8)$ & 2 & 6.3 & 13 & 6.9 & $0.06(0.81)$ & $0.90(0.19,4.18)$ \\
\hline
\end{tabular}




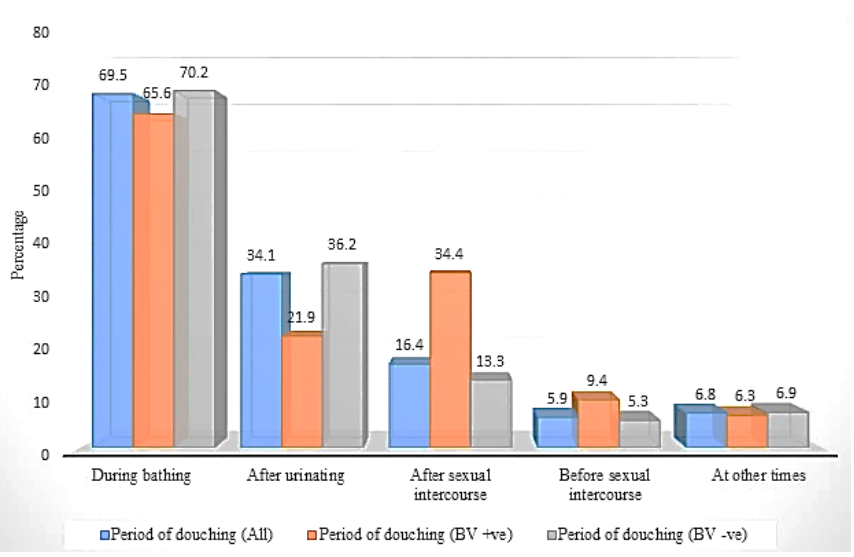

Figure 1 Period of douching among Bacterial vaginosis positive and negative pregnant women.

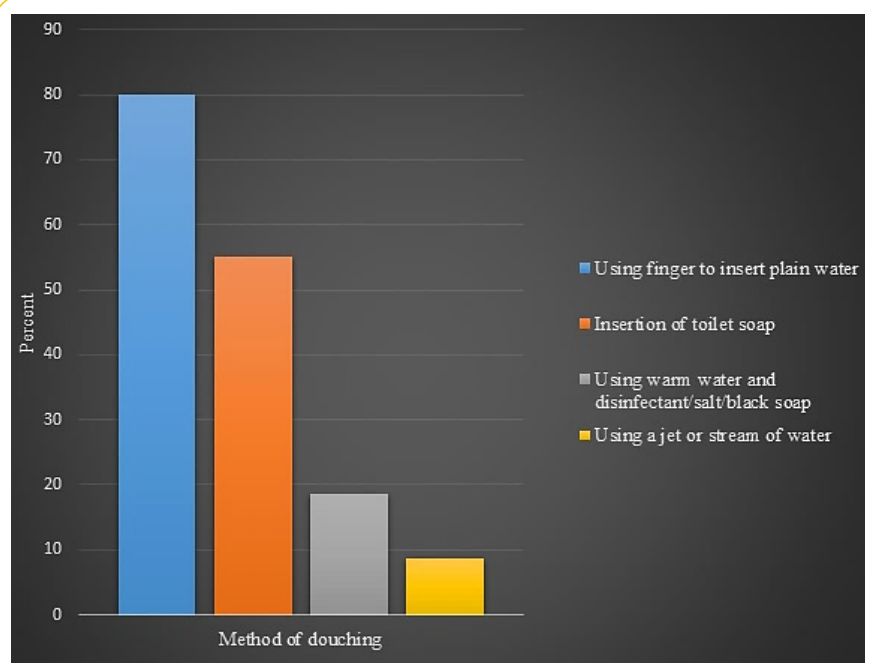

Figure 2 Percent distribution of douching methods among pregnant women in Zaria.

However, among those without Bacterial vaginosis, using finger to insert plain water for douching was also very prominent among those aged $25-29$ (89.7\%) and those without formal education (83.1\%). Douching during bathing was found more among those in the age group of $35-39$ (75.0\%) and those with no formal education $(89.8 \%)$.

Figure 3 shows morbidity pattern by age groupings depicting Bacterial vaginosis to be most prevalent among pregnant women aged 25-29 years but HIV positivity to be highest in age groups 20-24 (30.0\%) and age group 30-34 (30.0\%) respectively.

However, among those without Bacterial vaginosis, using finger to insert plain water for douching was also very prominent among those aged $25-29(89.7 \%)$ and those without formal education (83.1\%). Douching during bathing was found more among those in the age group of $35-39(75.0 \%)$ and those with no formal education (89.8\%).

Figure 3 shows morbidity pattern by age groupings depicting Bacterial vaginosis to be most prevalent among pregnant women aged 25-29 years but HIV positivity to be highest in age groups $20-24(30.0 \%)$ and age group 30-34 (30.0\%) respectively.

\section{Discussion}

It may seem quite natural for women in reproductive age group to douche either regularly or periodically. Whether douching is necessary or not or whether it is a tradition handed down from the past is still contentious. Since the vagina produces secretions at various times and since menstrual flow exit through the vagina, it might seem customary for women to douche. Douching may have started early in life while mothers bathe their newborn females. At such instances, especially in sub-Saharan Africa, powdery substances are often administered over parts of the baby's body including the female genitalia.

The exact age when douching starts is not yet established. Foch et al. reported an average age of 17 years among women who douche in USA which was confirmed by [30]. However, it seems douching probably commences at the time of debutant into sexual activity and continues till older age but for different reasons. One of the possible reasons for douching in younger age may be to wash out semen after sexual intercourse to prevent getting pregnant if condom is not used. This study however observed that douching was more prevalent in younger pregnant women than in those in their 30's or 40's. It is supposed that pregnancy may be the outcome of a douching failed to prevent it.

One of the main findings of this study high prevalence of douching among the Hausa-Fulani ethnic group of Northern Nigeria. The $85.5 \%$ prevalence of douching found in this study was higher than the $70 \%$ reported in Egypt [31], the $58.5 \%$ reported among African American women in child-bearing age [32], close to the $90 \%$ documented in a South African study [33] but lower than the $97 \%$ reported in Cote d'Ivoire (La Ruche et al. 1999). Vaginal douching appears to be common especially among Black women of African descent in general, by a third of women in the USA $[34,35]$ as well as in a large proportion of women in Turkey [8].

Using fingers to insert plain water was found to be the most common method of douching among as reported by $80 \%$ of women in this study. Very few other studies reported douching with plain water. Incidentally, bacterial vaginosis was found more among those aged 25-29 years with no formal education, who used fingers to insert plain water than among any other sub-group. Education is one of the various factors which impact women's douching behaviors, the others being social and cultural influences (Cottrell). It is possible that using fingers to insert plain water for douching may have a causal relationship with vaginal infections, such as Bacterial vaginosis observed in the patients. Plain water is not always free from pathogens, neither are hands. This may be the most important singular iatrogenic factor by which pathogens are introduced to the vagina, especially in early age groups between 20-29 years when douching was found to be more common. Using fingers to insert plain water may not be associated with 'dry sex', a process of drying and tightening the vagina in preparation for sexual intercourse as reported by Bekinska, et al. but to personal hygiene of the vagina or when there is an indication of a sexually transmitted infection [36]. Selfmedication is rampant in Nigeria [37] and douching may be the first step in home-management of an impending serious vaginal infection prior to clinic attendance. Douching was observed to 


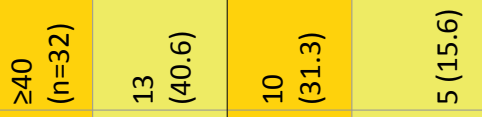

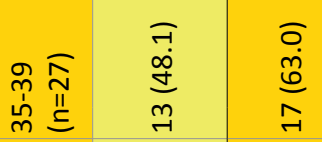

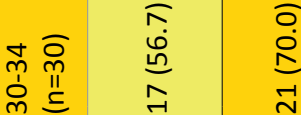

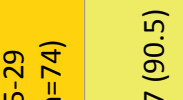

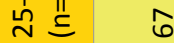

站 竞

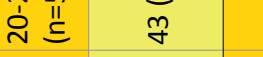

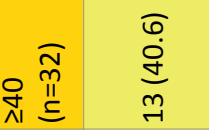

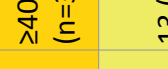

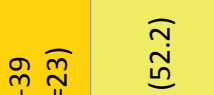
要

穴视

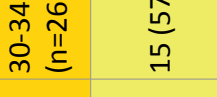

楆

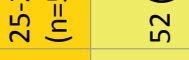

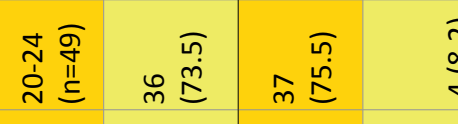

일

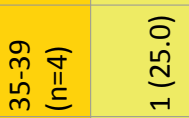

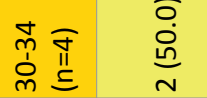

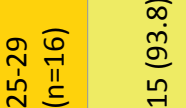

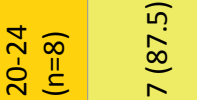

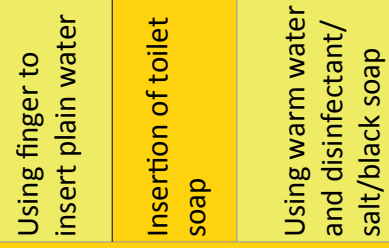

व बक्ष

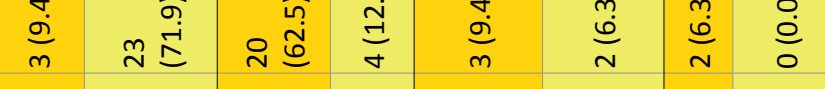

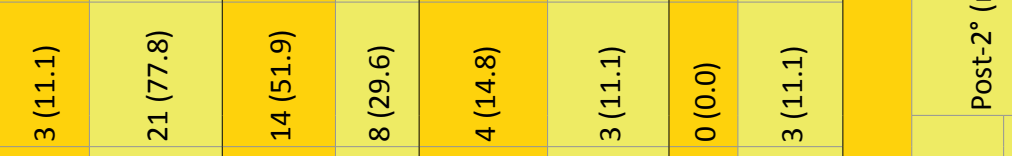
㩊

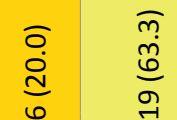
离

完

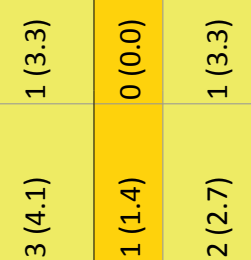

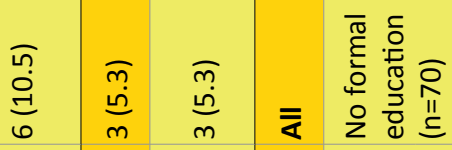

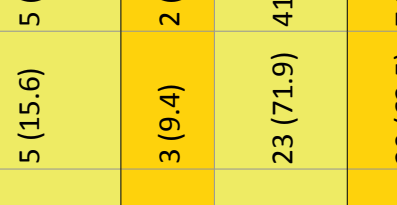
葛

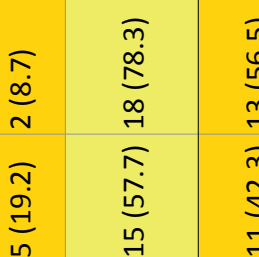

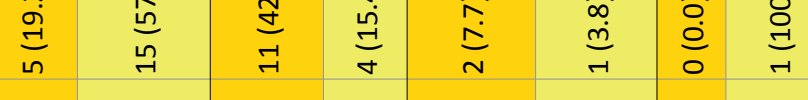

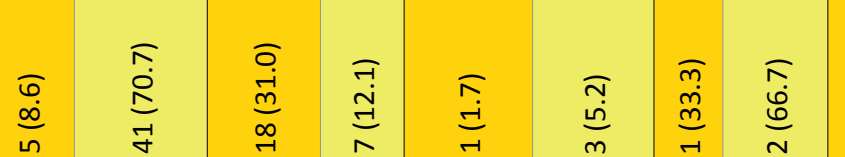

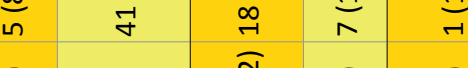

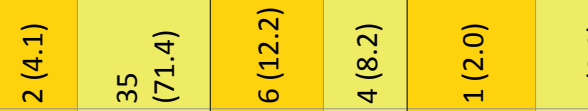

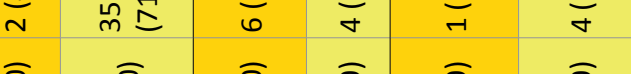

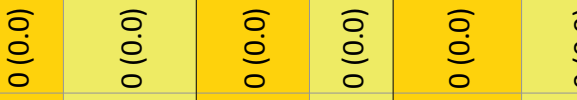

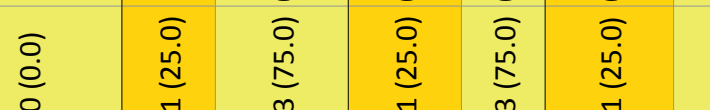

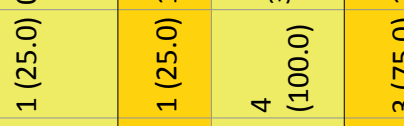

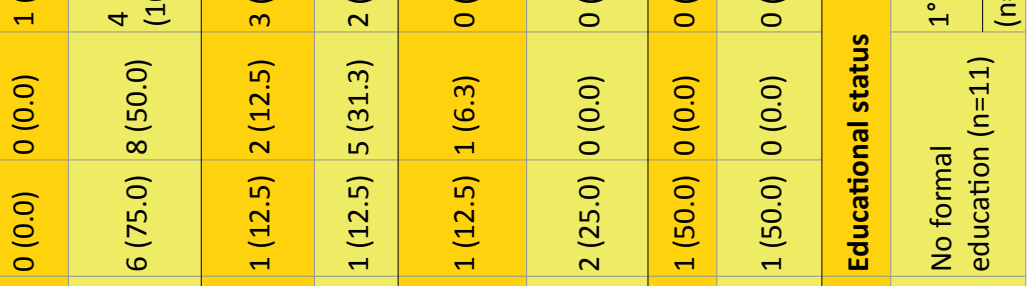

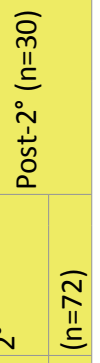

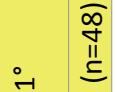

部画

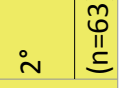
要

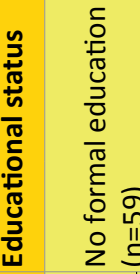
离 i $\therefore$ 画 


\begin{tabular}{|c|c|c|c|c|c|c|c|c|c|c|}
\hline $\begin{array}{l}\overline{0} \\
0 \\
\text { m. } \\
\sigma\end{array}$ & $\begin{array}{l}\text { o. } \\
\dot{g} \\
\underset{y}{q}\end{array}$ & 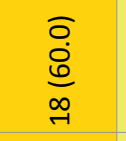 & $\begin{array}{l}\bar{m} \\
\stackrel{m}{m} \\
\stackrel{m}{0} \\
\text { - }\end{array}$ & 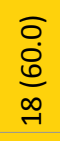 & $\underset{\substack{m \\
g}}{\stackrel{\sigma}{\sigma}}$ & 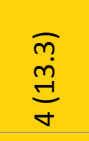 & $\begin{array}{l}\hat{T} \\
\stackrel{\omega}{\omega}\end{array}$ & $\begin{array}{l}\underset{T}{\dot{b}} \\
\stackrel{\theta}{n}\end{array}$ & 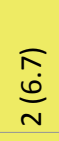 & 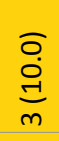 \\
\hline 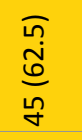 & $\begin{array}{l}\sigma \\
\dot{\sigma} \\
\hat{\omega} \\
\vec{\sigma}\end{array}$ & $\begin{array}{l}\overrightarrow{7} \\
\substack{0 \\
\rightarrow \\
m \\
\rightarrow}\end{array}$ & $\frac{\pi}{\stackrel{a}{n}}$ & 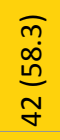 & $\begin{array}{l}\stackrel{\pi}{\Xi} \\
\stackrel{\Xi}{a}\end{array}$ & $\underset{\infty}{\stackrel{-}{-}}$ & $\begin{array}{l}\bar{a} \\
\stackrel{\omega}{n}\end{array}$ & $\begin{array}{l}\underset{\mathfrak{d}}{\mathrm{d}} \\
\mathrm{m}\end{array}$ & 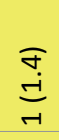 & $\begin{array}{l}\stackrel{\infty}{d} \\
\underset{\sim}{\sim}\end{array}$ \\
\hline 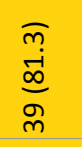 & $\begin{array}{l}\bar{\sigma} \\
\stackrel{0}{0} \\
\stackrel{0}{0} \\
\text { ন }\end{array}$ & $\underset{\sigma}{\stackrel{\pi}{\leftrightarrows}}$ & $\underset{-\underset{J}{d}}{\stackrel{\vec{d}}{d}}$ & $\begin{array}{l}\overline{0} \\
\dot{j} \\
\underline{0} \\
\vec{m}\end{array}$ & $\begin{array}{l}\bar{\sigma} \\
\dot{m} \\
\stackrel{m}{\stackrel{n}{7}}\end{array}$ & $\begin{array}{l}\underset{\sigma}{\mathrm{d}} \\
\underset{\sim}{-1}\end{array}$ & $\begin{array}{l}\bar{m} \\
\stackrel{\omega}{m}\end{array}$ & 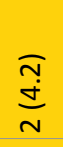 & $\begin{array}{l}\overline{0} \\
\stackrel{0}{0} \\
0\end{array}$ & 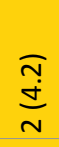 \\
\hline 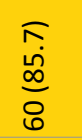 & 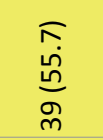 & 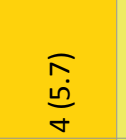 & $\underset{\sim}{\underset{\sim}{\vec{J}}}$ & $\begin{array}{l}\sigma \\
\infty \\
\infty \\
\infty \\
\sigma \\
\sigma\end{array}$ & $\begin{array}{l}\bar{n} \\
\dot{\sigma} \\
\stackrel{y}{y}\end{array}$ & 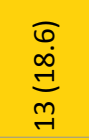 & 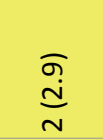 & 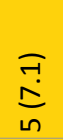 & 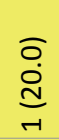 & $\begin{array}{l}0 \\
\dot{0} \\
\stackrel{\infty}{\sigma} \\
\end{array}$ \\
\hline$\stackrel{\text { ăd }}{\stackrel{\text { d }}{n}}$ & $\begin{array}{l}\underset{m}{\stackrel{n}{m}} \\
\stackrel{m}{0} \\
\frac{-}{9}\end{array}$ & 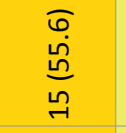 & $\begin{array}{l}\overline{0} \\
\stackrel{D}{D} \\
\infty\end{array}$ & $\begin{array}{l}\bar{m} \\
\stackrel{0}{0} \\
\underline{\sigma}\end{array}$ & $\begin{array}{l}\underset{\infty}{\infty} \\
\stackrel{+}{ \pm} \\
\forall\end{array}$ & $\frac{\vec{I}}{\stackrel{-}{-}}$ & 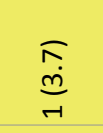 & 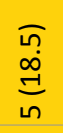 & $\begin{array}{l}\overline{0} \\
\stackrel{i}{+} \\
\sim\end{array}$ & $\begin{array}{l}\overline{0} \\
\dot{0} \\
\dot{0} \\
\mathrm{~m}\end{array}$ \\
\hline $\begin{array}{l}\vec{y} \\
\hat{\beta} \\
\underline{0} \\
\vec{y}\end{array}$ & 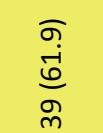 & 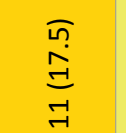 & $\underset{n}{\stackrel{I}{ت}}$ & $\begin{array}{l}\bar{\sigma} \\
\overrightarrow{0} \\
\vec{\sigma} \\
\bar{m}\end{array}$ & $\underset{\infty}{\stackrel{乛}{\Xi}}$ & $\begin{array}{l}\bar{m} \\
\dot{\omega} \\
\stackrel{v}{\sigma}\end{array}$ & $\begin{array}{l}\bar{\infty} \\
\stackrel{\dot{d}}{m}\end{array}$ & $\begin{array}{l}\bar{\infty} \\
\dot{j} \\
m\end{array}$ & $\underset{\substack{n \\
m}}{\stackrel{n}{r}}$ & $\begin{array}{l}\widetilde{\hat{\theta}} \\
\dot{\theta} \\
\stackrel{v}{v}\end{array}$ \\
\hline $\begin{array}{l}\bar{n} \\
\text { g. } \\
\vec{n} \\
\vec{m}\end{array}$ & $\begin{array}{l}\overline{7} \\
\dot{j} \\
\stackrel{0}{\omega}\end{array}$ & 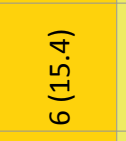 & $\underset{-1}{\stackrel{\sigma}{d}}$ & $\begin{array}{l}\frac{\pi}{0} \\
\dot{0} \\
\stackrel{d}{d}\end{array}$ & $\begin{array}{l}\pi n \\
\infty \\
\infty \\
\stackrel{n}{n} \\
\end{array}$ & 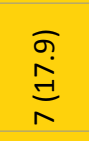 & 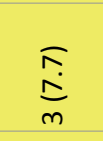 & $\underset{-1}{\stackrel{0}{d}}$ & $\begin{array}{l}0 \\
\stackrel{0}{0} \\
0\end{array}$ & 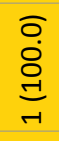 \\
\hline $\begin{array}{l}\bar{F} \\
\dot{\infty} \\
\infty \\
\stackrel{0}{g}\end{array}$ & $\begin{array}{l}\overline{0} \\
\dot{n} \\
\tilde{n} \\
\dot{m}\end{array}$ & $\begin{array}{l}\bar{\infty} \\
\stackrel{\varphi}{\theta} \\
\vec{\sigma}\end{array}$ & $\underset{r}{\stackrel{\Gamma}{i}}$ & 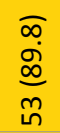 & 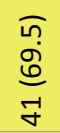 & $\begin{array}{l}\sigma \\
\infty \\
\infty \\
\Xi \\
\exists \\
\exists\end{array}$ & 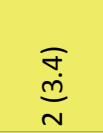 & $\begin{array}{l}\widehat{\infty} \\
e \\
\dot{\sigma}\end{array}$ & 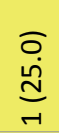 & 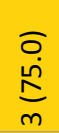 \\
\hline $\begin{array}{l}\widetilde{T} \\
\hat{b} \\
\stackrel{b}{v}\end{array}$ & $\begin{array}{l}\widetilde{T} \\
\dot{b} \\
\stackrel{b}{\sim} \\
\sim\end{array}$ & 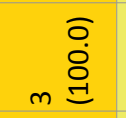 & $\begin{array}{l}\bar{T} \\
\dot{b} \\
\stackrel{\sigma}{\sigma} \\
\sim\end{array}$ & $\begin{array}{l}\pi \\
\hat{\theta} \\
\stackrel{\theta}{\sim} \\
\sim\end{array}$ & $\begin{array}{l}0 \\
0 \\
0 \\
0\end{array}$ & $\underset{\substack{n \\
m}}{\bar{m}}$ & 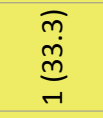 & 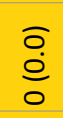 & $\begin{array}{l}\bar{\partial} \\
\stackrel{0}{0} \\
0\end{array}$ & $\begin{array}{l}0 \\
0 \\
0 \\
0\end{array}$ \\
\hline $\begin{array}{l}\underset{J}{J} \\
\underset{J}{J}\end{array}$ & $\underset{\sim}{\stackrel{\widetilde{N}}{\stackrel{N}{d}}}$ & $\underset{\sim}{\stackrel{\mathbb{N}}{N}}$ & $\begin{array}{l}\overline{0} \\
\stackrel{\varrho}{0} \\
0\end{array}$ & $\begin{array}{l}\bar{m} \\
\stackrel{m}{m} \\
m\end{array}$ & $\begin{array}{l}\underset{-}{-} \\
\stackrel{-}{\Xi} \\
-1\end{array}$ & $\begin{array}{l}\vec{J} \\
\underset{\forall}{J}\end{array}$ & $\underset{\sim}{\stackrel{\widetilde{N}}{\underset{N}{N}}}$ & $\frac{0}{0}$ & $\frac{0}{0}$ & 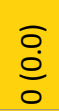 \\
\hline $\begin{array}{l}\sigma \\
\infty \\
\infty \\
\infty\end{array}$ & $\begin{array}{l}\vec{J} \\
\dot{J} \\
\dot{J}\end{array}$ & 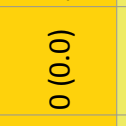 & $\begin{array}{l}0 \\
\stackrel{0}{0}\end{array}$ & $\stackrel{\infty}{\stackrel{\infty}{\Sigma}}$ & $\underset{\sim}{\stackrel{N}{N}}$ & $\begin{array}{l}\vec{J} \\
\dot{J} \\
\vec{J}\end{array}$ & 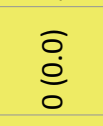 & $\underset{\sim}{\stackrel{\vec{I}}{ت}}$ & $\begin{array}{l}0 \\
\stackrel{0}{0} \\
0\end{array}$ & $\underset{r-1}{\stackrel{\vec{I}}{\vec{I}}}$ \\
\hline 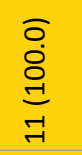 & 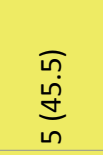 & $\begin{array}{l}\bar{\partial} \\
\dot{0} \\
0\end{array}$ & $\begin{array}{l}\bar{\partial} \\
\stackrel{0}{0} \\
0\end{array}$ & $\begin{array}{l}\bar{\infty} \\
-i \\
\infty \\
\sigma\end{array}$ & $\begin{array}{l}\underset{f}{d} \\
\dot{d} \\
\stackrel{\sigma}{\sigma}\end{array}$ & $\begin{array}{l}\underset{\sim}{\infty} \\
\substack{\infty \\
\stackrel{\sim}{*}}\end{array}$ & 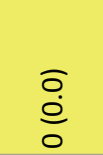 & $\frac{\vec{\sigma}}{\sigma}$ & 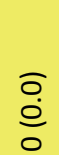 & 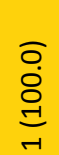 \\
\hline 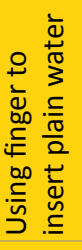 & 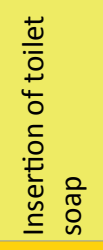 & 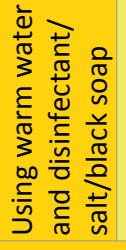 & 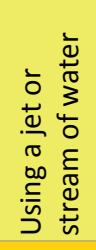 & 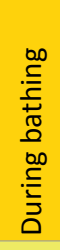 & 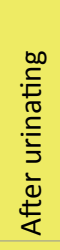 & 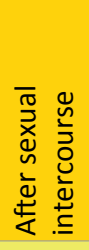 & 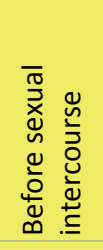 & 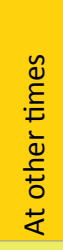 & 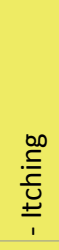 & 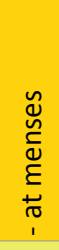 \\
\hline \multicolumn{4}{|c|}{ 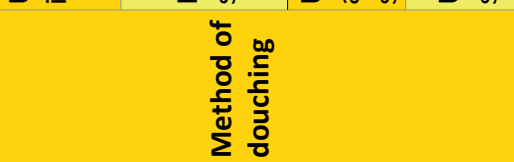 } & \multicolumn{7}{|c|}{ 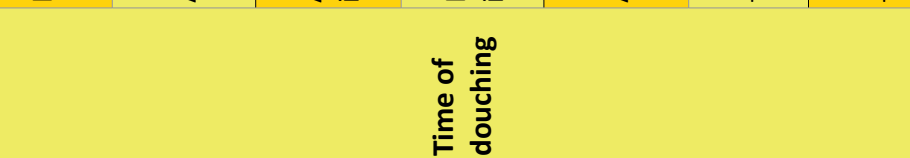 } \\
\hline
\end{tabular}




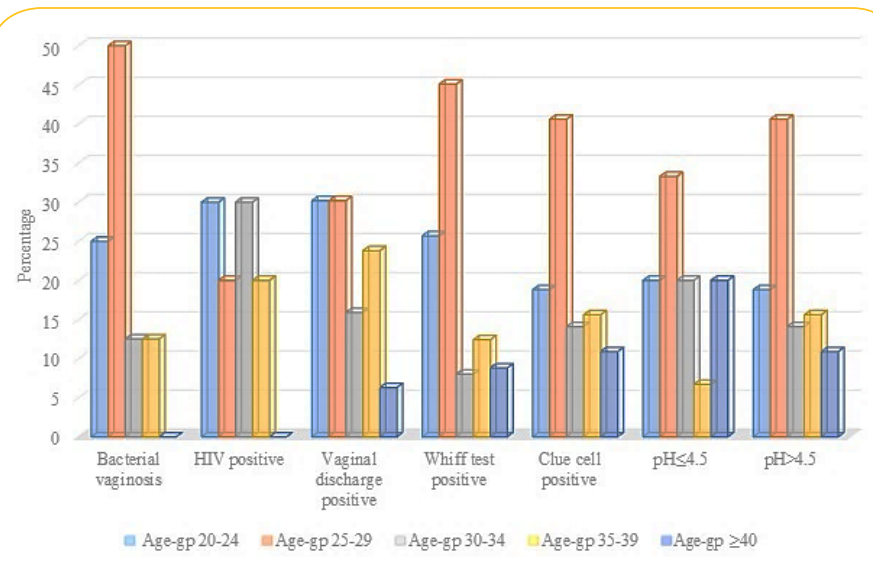

Figure 3 Morbidity pattern of study subjects by age group (years).

be less common before than after sexual intercourse, a finding in line with the suggestion that frequent douching is significantly more associated with douching after sex [38]. This may lend credence to the notion of douching for cleanliness.

It is surprising that method of douching also differed by educational status. Douching was observed more among women with no formal education or among those with only primary education. This agrees with other studies that douching is more prevalent among females of low educational $[15,39]$ and socioeconomic status [7]. However, our result of douching being more prominent in younger age groups was in contrast with what Declemente et al. reported [7].

Dettol (chloroxylenol, $4 \mathrm{mg} / 100 \mathrm{ml}$ ) used by $18.6 \%$ of pregnant women in this study was the most common disinfectant for douching, especially among those between the ages of 25 to 39 . This is much lower than the $67 \%$ of women who use Dettol as disinfectant in another study [33]. There may be an economic and/or educational factor to the use of Dettol as $60 \%$ of those with post-secondary education applied this disinfectant during douching in contrast to only $15 \%$ of those without formal education.

Bacterial vaginosis was observed in $14.5 \%$ of pregnant women in this study, more in ages 20-29 than in other age groups and more among those with low than those with high educations status. Many studies have associated douching with various adverse reproductive and gynecologic consequences such as bacterial vaginosis, preterm birth, low-birth-weight infants, pelvic inflammatory disease, chlamydial infection, tubal pregnancy, higher rates of HIV transmission, and cervical cancer. The deleterious effects of douching cannot be over-emphasized.

\section{Conclusion}

Douching was a common practice among the Hausa-Fulani ethnic group in Nigeria amongst whom the most practice of douching was inserting plain water with fingers followed by insertion of toilet soap and using warm water and disinfectant such as Dettol. Douching seemed to be more associated with personal hygiene than cleaning after menstrual flow. A high proportion of women in this study douche during bathing and after micturition. A sizable proportion also douche after and not before sexual intercourse. Bacterial vaginosis was found more among those who used fingers to insert plain water for douching, especially those aged 25-29 years and those with no formal education. An aggressive health education, using the print and electronic media, should give health education to women, especially those in early reproductive age group, on the risks associated with douching such as pelvic inflammatory disease (PID), endometriosis, ascending and upper genital tract infection, infertility and ectopic pregnancy, among others. A multi-center study on anthropological factors associated with douching is encouraged. Survey of the true prevalence of douching in various cohorts of African women associated with gynecological, obstetric, and other pathological indices should be embarked upon for the health of women and their offspring.

\section{Study Limitations}

This study has some limitations. First, only pregnant women were studied and, in this part of the country, these usually come for their first ANC at later stages of pregnancy. Therefore, conclusions based on our findings are limited to this cohort of women and may not be generalizable to other women who are not pregnant. Secondly, the sample size is small and stratification makes it even smaller. Younger women aged less than 20 were excluded from this study and it is a well-known fact that age of debutant into sexual activity is much younger than 20 in this location. Therefore, douching practices of young girls are not represented in this study. Thirdly, this study focused mainly on douching practice and information on concomitant vaginal infections is not well focused upon. However, Bacterial vaginosis in relation to douching practices appears to be undocumented in Nigeria, thus the attention given to it in this paper. This study did not identify risk factors for acquiring bacterial vaginosis or any other diseases observed through laboratory investigations. A prospective study to look at the effect of douching on pregnancy outcome is desirable in the future. Patients were observed at health facility setting, which mitigates against the socio-cultural, anthropological, and genealogical background to douching practices. Finally, the Hausa-Fulani ethnic group is just one out of hundreds of ethnic groups in Nigeria and findings in this study do not necessarily apply to douching practices or vaginal infection in other ethnic groups or other geo-political locations of the country.

\section{Disclosure}

The authors have nothing to declare. 


\section{References}

Cottrell BH, Close FT (2008) Vaginal douching among university women in the southeastern United States. J Am Coll Health 56: 415-421.

Shaaban OM, Youssef AE, Khodry MM, Mostafa SA (2013) Vaginal douching by women with vulvo vaginitis and relation to reproductive health hazards. BMC Womens Health 13-1.

Shaaban OM, Abbas AM, Moharram AM, Farhan MM, Hassanen IH (2015) Does vaginal douching affect the type of candida vulvo vaginal infection? Med Mycol 53: 817-827.

Cottrell BH (2003) Vaginal douching. J Obstet Gynecol Neonatal Nurs 32: $12-18$

Czerwinski BS (1996) Adult feminine hygiene practices. Appl Nurs Res 9: 123-129.

Martino JL, Youngpairoj S, Vermund SH (2004) Vaginal douching: Personal practices and public policies. J Womens Health 13: 1048-1065.

Diclemente RJ, Young AM, Painter JL, Wingood GM, Rose E, et al. (2012) Prevalence and correlates of recent vaginal douching among African American adolescent females. J Pediatr Adolesc Gynecol 25: 48-53.

Erbil N, Alışarlı A, Terzi HÇ, Ozdemir K, Kuş Y (2012) Vaginal douching practices among Turkish married women. Gynecol Obstet Invest 73 : 152-157.

Kukulu K (2006) Vaginal douching practices and beliefs in Turkey. Cult Health Sex 8: 371-378.

10 Funkhouser E, Hayes TD, Vermund SH (2002) Vaginal douching practices among women attending a university in the southern United States. J Am Coll Health 50: 177-182.

Korte JE, Shain RN, Holden AE, Piper JM, Perdue ST, et al. (2004) Reduction in sexual risk behaviors and infection rates among African Americans and Mexican Americans. Sex Transm Dis 31: 166-173.

2 Vermund SH, Sarr M, Murphy DA, Levin L, Abdalian SE, et al. (2001) Douching practices among HIV infected and uninfected adolescents in the United States. J Adolesc Health 29: 80-86.

Rajamanoharan S, Low N, Jones SB, Pozniak AL (1999) Bacterial vaginosis, ethnicity, and the use of genital cleaning agents: a case control study. Sex Transm Dis 26: 404-409.

Foch BJ, McDaniel ND, Chacko MR (2001) Racial differences in vaginal douching knowledge, attitude, and practices among sexually active adolescents. J Pediatr Adolesc Gynecol 14: 29-33.

5 Vermund SH, Sarr M, Murphy DA, LevinL, Abdalian SE, et al. (2001) Douching practices among HIV infected and uninfected adolescents in the United States. J Adolesc Health 29: 80-86.

16 Lazcano-Ponce E, Smith JS, Muñoz N, Conde-Glez CJ, Juárez-Figueroa $L$, et al. (2001) High prevalence of antibodies to herpes simplex virus type 2 among middle-aged women in Mexico City, Mexico: A population-based study. Sex Transm Dis 28: 270-276.

17 Cherpes TL, Meyn LA, Krohn MA, Hillier SL (2003) Risk factors for infection with herpes simplex virus type 2: Role of smoking, douching, uncircumcised males, and vaginal flora. Sex Transm Dis 30: 405-410.

8 Holzman C, Leventhal JM, Qui H, Ones NM, Wang J (2001) Factors linked to bacterial vaginosis in nonpregnant women. Am J Public Health 91: 1664-1670.

Scholes D, Stergachis A, Ichikawa LE, Heidrich FE, Holmes KK, et al. (1998) Vaginal douching as a risk factor for cervical Chlamydia trachomatis infection. Obstet Gynecol 91: 993-997.

20 Joesoef MR, Karundeng A, Runtupalit C, Moran JS, Lewis JS, et al. (2001)
High rate of bacterial vaginosis among women with intrauterine devices in Manado, Indonesia. Contraception 64: 169-172.

Ness RB, Soper DE, Holley RL, Peipert J, Randall H, et al. (2001) Douching and endometriosis: Results from the PID evaluation and clinical health (PEACH) survey. Sex Transm Dis 28: 240-245.

Bayo S, Bosch FX, de Sanjosé S, Muñoz N, Combita AL, et al. (2002) Risk factors of invasive cervical cancer in Mali. Int J Epidemiol 31: 202-209.

Rothman KJ, Funch DP, Alfredson T, Brady J, Dreyer NA (2003) Randomized field trial of vaginal douching, pelvic inflammatory disease and pregnancy. Epidemiology14: 340-348.

Kent HL (1991) Epidemiology of vaginitis. AAm J Obstet Gynecol 165: 1168-1176.

Ingalls RR, Rice PA (1996) Sexually transmitted diseases. In: Manning $S$ (Ed.) Textbook of primary care medicine. St. Louis, Mo:Mosby-Year Book 856-857.

Schaaf VM, Perez-Stable EJ, Borchardt K (1990) The limited value of symptoms and signs in the diagnosis of vaginal infections.

Berg AO, Heidrich FE, Finn SD, Bergman JJ, Wood RW, et al. (1984) Establishing the cause of genitourinary symptoms in women in a family practice: Comparison of clinical examination and comprehensive microbiology. JAMA 251: 620-625.

8 Chatwani AJ, Hassan S, Rahimi S, Jeronis S, Dandolu V (2006) Douching with water works device for perceived vaginal odor with or without complaints of discharge in women with no infectious cause of vaginitis: A pilot study. Infect Dis Obstet Gynecol 1-4.

Halperin DT (1999) Dry sex practices and HIV infection in the Dominican Republic of Haiti. Sex Transm Inf 75: 45-446.

Merchant JS, Oh K, Klerman LV (1999) Douching: a problem for adolescent girls and young women. Arch Pediatr Adolesc Med 153 834-837.

1 Abbas AM, Shaaban OM, Badran SM, Shaltout AS, Nasr A, et al. (2016) Risk factors and health hazards of vaginal infections in upper Egypt: A cross sectional study. Thai J Obstet Gynecol 24: 50-56.

Hayley M, Sherman SG, Nanda J, Chambers-Thomas T, Barnes M, et al. (2010) What has changed about vaginal douching among African American mothers and daughters? Public Health Nurs 27: 418-424.

Morar NS, Ramjee G, Gouws E, Wilkinson D (2003) Vaginal douching and vaginal substance use among sex workers in KwaZulu-Natal, South Africa. S Afr J Sci 99: 371-374.

4. La Ruche G, Messou N, Ali-Napo L, Noba V, Faye-Ketté H, et al. (1999) Vaginal douching: Association with lower genital tract infections in African pregnant women. Sex Transm Dis 26: 191-196.

Cottrell BH (2010) An updated review of evidence to discourage douching. Am J Matern Child Nurs 35: 102-107.

Bekinska ME, Rees HV, Kleinschmidt I, McIntyre J (1999) The practice and prevalence of dry sex among men and women in South Africa: A risk factor for sexually transmitted infections? Sex Transm Inf 75: 178-180.

Afolabi AO (2008) Factors influencing the pattern of self-medication in an adult Nigerian population. Ann Afr Med 7: 120-127.

3 Annang L, Grimley DM, Hook EW (2006) Vaginal douche practices among black women at risk: Exploring douching prevalence, reasons for douching, and sexually transmitted disease infection. Sex Transm Dis 33: $215-219$.

Funkhouser E, Pulley L, Leuschen G, Costello C, Hook E, et al. (2002) Douching beliefs and practices among black and white women. $J$ Womens Health Gend Based Med 11: 29-37. 